\title{
Nanomedicine applications in the treatment of breast cancer: current state of the art
}

\author{
This article was published in the following Dove Press journal: \\ International Journal of Nanomedicine \\ 16 August 2017 \\ Number of times this article has been viewed
}

\author{
Di Wu \\ Mengjie Si \\ Hui-Yi Xue \\ Ho-Lun Wong \\ Department of Pharmaceutical \\ Sciences, Temple University School \\ of Pharmacy, Philadelphia, PA, USA
}

Correspondence: Hui-Yi Xue;

Ho-Lun Wong

Department of Pharmaceutical Sciences, Temple University School of Pharmacy, 3307 North Broad Street, Philadelphia, PA 19140, USA

Tel +I 2 I5 $7078173 ;+$ I 2157077447

Fax + I $2157073678 ;+$ I 2157073678

Email ho-lun.wong@temple.edu;

joannex@temple.edu

\begin{abstract}
Breast cancer is the most common malignant disease in women worldwide, but the current drug therapy is far from optimal as indicated by the high death rate of breast cancer patients. Nanomedicine is a promising alternative for breast cancer treatment. Nanomedicine products such as Doxil ${ }^{\circledR}$ and Abraxane ${ }^{\circledR}$ have already been extensively used for breast cancer adjuvant therapy with favorable clinical outcomes. However, these products were originally designed for generic anticancer purpose and not specifically for breast cancer treatment. With better understanding of the molecular biology of breast cancer, a number of novel promising nanotherapeutic strategies and devices have been developed in recent years. In this review, we will first give an overview of the current breast cancer treatment and the updated status of nanomedicine use in clinical setting, then discuss the latest important trends in designing breast cancer nanomedicine, including passive and active cancer cell targeting, breast cancer stem cell targeting, tumor microenvironment-based nanotherapy and combination nanotherapy of drugresistant breast cancer. Researchers may get insight from these strategies to design and develop nanomedicine that is more tailored for breast cancer to achieve further improvements in cancer specificity, antitumorigenic effect, antimetastasis effect and drug resistance reversal effect.

Keywords: nanomedicine, breast cancer, targeted delivery, drug therapy, drug resistance, tumor microenvironment
\end{abstract}

\section{Introduction}

Breast cancer is the most common and lethal cancer type in women worldwide. ${ }^{1}$ The global incidence of breast cancer has increased by over $20 \%$ since $2008 .{ }^{2}$ Close to 1.5 million new cases of breast cancer are reported each year, accounting for $25 \%$ of all cancer cases. Overall, breast cancer is the second leading cause of mortality just behind lung cancer, and among females, it has long been the top cause of cancer death ( $15 \%$ of all female cancer patients). ${ }^{2}$ Just in the USA alone, breast cancer is expected to cause about 40,000 deaths of women in $2017 .{ }^{3}$ Discovering new effective and safe forms of treatment for this prevalent and deadly malignant disease is, therefore, critical.

Breast cancer is a highly heterogeneous disease. Consequently, breast cancer has fairly complex classifications. ${ }^{4,5}$ As of today, breast cancer is often first classified based on histopathologic type. The majority of breast cancer cases are invasive ductal carcinoma, but other less-prevalent subtypes still draw attention because of their aggressiveness and occurrence in different patient subpopulations (eg, inflammatory breast cancer often occurs in younger patients). ${ }^{6}$ The next biggest concern is usually the stage of the tumor. As the disease progresses, the primary tumor within the breast (stage 1) frequently spreads to the tissues and lymph nodes nearby (stage 2-3) or the distant organs (distant metastasis, ie, stage 4). ${ }^{4}$ Lung, bone, liver and brain are the most 
frequent sites of breast cancer metastasis. ${ }^{7}$ Staging is crucial because once the tumor metastasizes, the mortality rate dramatically increases. In addition, breast cancer is also classified based on the grade and the molecular subtypes, including luminal A, luminal B, HER2 type and triple-negative type. ${ }^{4}$ It should be noted that the various classification parameters are not independent from one another. For instance, tumors of high grade and without expressing hormone receptors (eg, TNBC) are significantly more aggressive and tend to metastasize. ${ }^{8,9}$ Regardless, once cancer metastasizes, the value of many standard treatment options will considerably diminish as they are either not suitable for systemic use or their effectiveness against metastasized, high-grade cancer is far from optimal. ${ }^{8}$ We are, therefore, still in dire need of new treatments that can better tackle breast cancer.

Nanomedicine is one of these promising new therapeutic options. By definition, nanomedicine refers to biomedical application of materials with at least one dimension below $100 \mathrm{~nm}$, although devices of 100-200 nm are often considered nanomedicine in practice. ${ }^{10}$ Examples of nanomedicine range from liposomes, nanoparticles, micelles, dendrimers, nanotubes and so on, and they can be made of diverse materials including lipids, phospholipids, polymers, proteins, inorganic materials and a combination of them. ${ }^{10,11}$ Some of them, such as liposomes (eg, Doxil ${ }^{\circledR}$, Janssen Products, Titusville, NJ, USA) and nanoparticles (eg, Abraxane ${ }^{\circledR}$ ), are already widely used for clinical treatment of breast cancer with success. These products, however, were originally developed as generic anticancer drug carriers. With better understanding of molecular biology of breast cancer, several promising nanodelivery strategies more tailored for breast cancer are actively explored in recent years. It is, therefore, good time update on the current status of and the most recent trends in this field. It should be noted that nanomedicine can serve a broad range of functions for cancer patients besides treatment, including tissue repairing, disease detection, cancer imaging and theranostic. ${ }^{10,12}$ This review will focus only on the treatment aspect, with emphasis on the advanced use of nanomaterials to carry anticancer agents (ie, as nanocarriers).

\section{Standard breast cancer treatment and potential inclusion of nanomedicine}

Currently, patients diagnosed with breast cancer are often given multimodality treatment that involves standard modalities such as surgery, radiation therapy and drug therapy, plus some optional complementary measures that range from acupuncture to diet management. ${ }^{13,14}$ The first two modalities are used mainly for eradicating the primary breast tumor and locoregional cancerous tissues. ${ }^{13}$ Their value tends to decline as the cancer progresses and metastasizes. Our focus is on the last modality, drug therapy, which serves to reduce the tumor burden and prevent, control or treat cancer metastasis. ${ }^{13}$ Breast cancer drug therapy often consists of hormonal therapy, which uses hormones or hormone-like drugs to suppress cancer cell proliferation, and chemotherapy, which mainly relies on killing cancer cells with cytotoxic compounds. ${ }^{13}$ In recent years, with the latest breakthroughs in molecular biology and immunotherapy, targeted therapies tailored to the specific pathophysiology of different breast cancer subtypes are increasingly included. This approach generally involves a small molecule drug or monoclonal antibody targeting a specific molecular pathway; therefore, cancer proliferation, progression, spreading and/or drug resistance can be prevented or controlled. ${ }^{14}$ The most famous targeted therapy so far is trastuzumab (ie, Herceptin), a humanized anti-HER2 monoclonal antibody. At present, the choice of adjuvant drug therapy is largely dependent on the breast cancer intrinsic subtype. Table 1 summarizes the standard drug therapy options.

Although drug therapy can achieve systemic treatment, their current success rates are typically suboptimal. There are several obstacles that limit their effectiveness. ${ }^{10,15,16}$ Table 2 summarizes these challenges. These challenges actually fall into three major categories. Items $1-4$ are issues derived from suboptimal biodistribution of the drug in body, that is, too little drug in tumor tissues (so, suboptimal efficacy) and too much in healthy tissues (so, high toxicity). Items 5-7 are related to the poor response to the drug even though it reaches the tumor, while the last two are related to the inherent properties of the drug or drug combination itself.

Nanomedicine has the potential to overcome at least some of these limitations. The extremely large surface areato-volume ratio of nanocarriers provides an opportunity to manipulate their surface properties for improved treatment, for example, cancer targeting, extended circulation, increased endocytosis and transcytosis, in order to gain more efficient access into tumor sites, metastatic sites and cancer cells. Moreover, by entrapping in or binding onto nanocarriers, the therapeutic agents can also gain better stability, increased solubility and controlled release kinetics. Drug combinations may also be co-delivered for increased synergistic or additive anticancer effects. ${ }^{10}$ The use of these features to tackle the limitations of breast cancer drug therapy is summarized in Table 2. 
Table I Molecular subtypes of breast cancer and their current standard drug therapy

\begin{tabular}{lllll}
\hline Molecular subtype & Other conditions & $\begin{array}{l}\text { Hormone } \\
\text { therapy }\end{array}$ & Chemotherapy & $\begin{array}{l}\text { Anti-HER2 } \\
\text { (trastuzumab) }\end{array}$ \\
\hline Luminal A & Low tumor burden & Yes & No & No \\
Luminal B & High tumor burden* or grade 3 & Yes & Yes & No \\
& HER2+ & Yes & Yes & Yes \\
HER2+ type & HER2- & Yes & Yes & Yes \\
Triple negative & Not applicable & No & Yes & No \\
\hline
\end{tabular}

Note: $* \geq 4$ positive LN, T3 or higher.

Abbreviations: HER2, human epidermal receptor 2; LN, lymph nodes.

There are several types of nanomaterials being used widely, such as solid-lipid nanoparticles, liposomes, and polymers. These nanocarriers help to improve the water solubility of anticancer drugs, increase drug delivery efficiency to tumor sites and enable site-targeted delivery of anticancer drugs. Although the advantages are appealing, these nanocarriers also hold some limitations, which include potential toxicity, possible immunogenicity and excretion mechanism. Table 3 lists the advantages and limitations of nanomaterials for targeted cancer therapeutic drug delivery and their current clinical trial status. ${ }^{17}$

\section{Updated status of nanomedicine application for breast cancer treatment}

As of today, only few nanomedicine products have gained US Food and Drug Administration (FDA) approval, and Doxil and Abraxane are the two most successful nanoformulations already widely used for breast cancer treatment in clinical settings. Their development and the ways how they are incorporated into the standard drug therapy for cancer treatment also provide good lessons for the nanomedicine researchers and clinicians. In addition, some promising nanoformulations that already entered clinical phase are also introduced.

\section{Doxil}

Doxil is the first FDA-approved nanodrug (1995). It is a PEGylated liposomal formulation (surface coating of PEG units) of doxorubicin with size of about $85 \mathrm{~nm}$ in diameter. ${ }^{18}$ Doxorubicin used to be the most important chemotherapy drug for breast cancer treatment; however, it is also notorious for causing congestive heart failure. ${ }^{19,20}$ This cardiotoxicity is dependent on its cumulative dose $(36 \%$ incidence when the total dose is $\left.>600 \mathrm{mg} / \mathrm{m}^{2}\right) .{ }^{20}$ Doxil was, therefore, designed

Table 2 A summary of the key challenges to breast cancer drug therapy and the ways nanomedicine can be used to tackle these challenges

\begin{tabular}{|c|c|}
\hline Challenges to breast cancer drug therapy & How nanomedicine can help \\
\hline I. Insufficient specificity for breast cancer & $\begin{array}{l}\text { Passive targeting and active targeting by nanomedicine to increase } \\
\text { tumor drug level and decrease noncancer drug levels }\end{array}$ \\
\hline 2. Inefficient access of drugs to metastatic sites such as brain and bone & $\begin{array}{l}\text { Many nanomedicine formulations inherently may improve brain } \\
\text { and bone penetration }\end{array}$ \\
\hline 3. Undesirable pharmacokinetics such as quick clearance and short half-life & Use of strategies such as PEGlyation to extend the circulation time \\
\hline $\begin{array}{l}\text { 4. Dose-limiting toxicity of the anticancer drugs or the excipients, for } \\
\text { example, surfactants and organic co-solvents }\end{array}$ & $\begin{array}{l}\text { Increased tumor specificity as above; controlled drug release from } \\
\text { nanocarrier; solvent-, surfactant-free nanoformulation }\end{array}$ \\
\hline $\begin{array}{l}\text { 5. Drug resistance at cellular level, for example, increased drug efflux } \\
\text { transport }\end{array}$ & $\begin{array}{l}\text { Passive and active targeting both may enhance endocytosis; some } \\
\text { nanoformulations may inhibit drug efflux mechanisms; co-delivery } \\
\text { of agents that target drug resistance mechanisms }\end{array}$ \\
\hline $\begin{array}{l}\text { 6. Drug resistance at tumor microenvironment level, for example, lower } \\
\mathrm{pH} \text {, hypoxia, cancer microenvironment crosstalk and so on }\end{array}$ & $\begin{array}{l}\text { Targeting tumor microenvironment; use of stimulus-responsive } \\
\text { nanoformulations such as } \mathrm{pH} \text {-responsive devices }\end{array}$ \\
\hline 7. Difficulty in eradicating cancer stem cells & Targeting cancer stem cells \\
\hline $\begin{array}{l}\text { 8. Undesirable pharmaceutical properties of the drugs, for example, low } \\
\text { aqueous solubility, poor in vivo stability }\end{array}$ & $\begin{array}{l}\text { Many nanocarriers can achieve drug solubilization and can protect } \\
\text { unstable drugs }\end{array}$ \\
\hline $\begin{array}{l}\text { 9. Suboptimal dosing schedule and sequence, especially when combinations } \\
\text { of multiple drugs are involved }\end{array}$ & $\begin{array}{l}\text { Careful optimization of dosing schedule and sequence; use of } \\
\text { nanocarrier to co-deliver multiple drugs }\end{array}$ \\
\hline
\end{tabular}

Abbreviation: PEG, polyethylene glycol. 
Table 3 Advantages and disadvantages of different nanomaterials for breast cancer treatment and current clinical trial status

\begin{tabular}{|c|c|c|c|}
\hline \multirow[t]{2}{*}{ Nanocarrier } & \multicolumn{2}{|l|}{ Targeted drug therapy } & \multirow{2}{*}{$\begin{array}{l}\text { Clinical trials for breast } \\
\text { cancer treatment }\end{array}$} \\
\hline & Advantage & Disadvantage & \\
\hline Solid-lipid nanoparticles & $\begin{array}{l}\text { Good solubility and bioavailability } \\
\text { due to organic makeup } \\
\text { Better control of drug release kinetic }\end{array}$ & $\begin{array}{l}\text { Low drug loading capacities } \\
\text { Possibly containing other colloidal } \\
\text { structures and complex physical state }\end{array}$ & NA \\
\hline Liposome & $\begin{array}{l}\text { Wide range of drug delivery } \\
\text { applications } \\
\text { Able to increase drug load and } \\
\text { minimize undesired drug activity }\end{array}$ & $\begin{array}{l}\text { Cationic lipids cause toxicity } \\
\text { Rapid degradation of the nanocarriers } \\
\text { by MPS }\end{array}$ & $\begin{array}{l}\text { Liposome-annamycin Phase I/II } \\
\text { (annamycin in lipid composition } \\
\text { of DSPC, DSPG and Tween for } \\
\text { intravenous administration) }\end{array}$ \\
\hline Polymeric & $\begin{array}{l}\text { Versatility in terms of chemical } \\
\text { composition }\end{array}$ & Degradation of the carrier & $\begin{array}{l}\text { Nanoxel Phase I (paclitaxel in } \\
\text { polymeric micelle) }\end{array}$ \\
\hline Magnetic nanoparticle & $\begin{array}{l}\text { Influenced by exterior magnetic field } \\
\text { for guided therapy, imaging and drug } \\
\text { delivery }\end{array}$ & Potential material toxicity & NA \\
\hline Quantum dots & $\begin{array}{l}\text { Fluorescent properties for imaging } \\
\text { and drug tracking }\end{array}$ & Potential material toxicity & NA \\
\hline Carbon nanotubes & $\begin{array}{l}\text { Able to penetrate and localize at } \\
\text { cellular level for the delivery of } \\
\text { chemotherapeutic and imaging agent }\end{array}$ & Potential material toxicity & NA \\
\hline
\end{tabular}

Abbreviations: DSPC, I,2-Distearoyl-sn-glycero-3-phosphocholine; DSPG, I,2-distearoyl-sn-glycero-3-phospho-(I'-rac-glycerol); MPS, mononuclear phagocyte system; NA, not applicable.

to reduce the systemic toxicity without compromising the anticancer effects of doxorubicin. It turns out to be the most successful product that demonstrates the capability of PEGylation to avoid premature elimination of nanocarriers by the reticuloendothelial system, so that extended circulation time can be achieved. It also confirms that the nanoformulation can achieve good intratumoral drug level by EPR passive targeting effect. ${ }^{18}$

Doxil was shown to markedly suppress tumor growth rates and improve survival. ${ }^{21}$ Moreover, the use of Doxil led to a major ( $\sim 3$-fold) risk reduction of cardiotoxicity versus free doxorubicin. ${ }^{22}$ In a Phase III trial, 22,509 women with metastatic breast cancer were treated with Doxil $50 \mathrm{mg} / \mathrm{m}^{2}$ or doxorubicin $60 \mathrm{mg} / \mathrm{m}^{2}$. Doxil and doxorubicin were comparable with respect to progression-free survival and overall survival. Overall risk of cardiotoxicity, however, was significantly higher with doxorubicin than Doxil.

With reduced cardiotoxicity, Doxil helps relieve the cumulative dose cap and enables lower risk, extended doxorubicin treatment and, thus, substantially increases the versatility of this drug. Doxil has already been combined with several other chemotherapy drugs (eg, cyclophosphamide and 5-fluorouracil, cisplatin and infusional fluorouracil, cyclophosphamide followed by paclitaxel) and targeted therapy such as trastuzumab for advanced breast cancer treatment in clinical trials. ${ }^{24-27}$ All of the studies indicated good efficacy and low toxicity including cardiotoxicity, even in elderly or cardiotoxicity-prone patients. ${ }^{26}$ It should be noted that a recent meta-analysis showed that although Doxil reduces cardiotoxicity substantially, it also leads to new side effects such as skin toxicity and mucositis, but these side effects are clinically much less serious than cariotoxicity. ${ }^{28}$ Overall, these studies provide good precedents that a nanomedicine can work effectively and safely in combination with standard drug therapy.

\section{Abraxane}

Abraxane is also known as nanoparticle albumin-bound paclitaxel or nab-paclitaxel. ${ }^{29}$ Paclitaxel is noncovalently bound onto $130 \mathrm{~nm}$ nanoparticle processed from human serum albumin. It was initially developed as a solvent-free paclitaxel formulation because the surfactant (Cremophor EL) and the co-solvent (ethanol) used to solubilize paclitaxel are responsible for high incidence of hypersensitivity reactions which call for premedication to relieve them. ${ }^{30} \mathrm{It}$ turned out that not only the solvent/surfactant-related adverse effects have been avoided and no premedication is required, by exploiting the natural interactions between albumin and the gp60/caveolin-1 receptor pathway, but also Abraxane is associated with rapid and preferential delivery and accumulation of paclitaxel at the tumor site. ${ }^{30-32}$ When compared with solvent-based paclitaxel, Abraxane is associated with a 9-fold greater penetration of paclitaxel into tissues via transportermediated pathways, a 33\% higher intratumoral drug concentration, a 10-fold higher mean maximal concentration of free paclitaxel and a 4-fold lower elimination rate. ${ }^{31-33}$ The clinical performance is also excellent. In GeparSepto trial, ${ }^{34}$ which involved 1,229 women with previously untreated unilateral 
or bilateral primary invasive breast cancer, it was found that substituting solvent-based paclitaxel with nab-paclitaxel significantly increased the proportion of patients achieving a pathologic complete response rate after anthracycline-based chemotherapy, and suggested that these results might lead to replacement of solvent-based paclitaxel by nab-paclitaxel for primary breast cancer treatment.

Clinicians have also explored the combination of Abraxane with other standard anticancer drugs. In a study in HER2+ breast cancer patients, the combination of Abraxane with carboplatin and trastuzumab was shown to be efficacious and generally safe. ${ }^{35}$ In another trial, it was shown that the addition of bevacizumab to Abraxane prior to dose-dense doxorubicin/cyclophosphamide significantly improved the pathologic complete response rate compared to chemotherapy alone in patients with triple-negative, locally advanced breast cancer or inflammatory breast cancer. ${ }^{36}$ In general, Abraxane has demonstrated comparable or superior efficacy over solvent-based paclitaxel for breast cancer treatment, and like Doxil, it can be safely combined with standard chemotherapy or targeted therapy.

\section{Other investigational nanoformulations}

This section will introduce some investigational nanoformulations that showed promise in clinical trials. Lipoplatin $^{\circledR}$ is a liposomal nanoparticle of $110 \mathrm{~nm}$ diameter that carries cisplatin. ${ }^{37}$ With the promising early data, Lipoplatin has been extensively evaluated and has successfully completed a number of clinical studies from Phase I to III trials. ${ }^{38}$ Its official indication is for non-small cell lung cancer. In a number of clinical trials, Lipoplatin demonstrated enhanced cisplatin retention in tumor tissue and substantially reduced renal toxicity, peripheral neuropathy, ototoxicity and myelotoxicity. ${ }^{39-41}$ This product also has potential to be included in the treatment of breast cancer. In a Phase II study of Lipoplatin/vinorelbine combination in HER2/neu-negative metastatic breast cancer, complete response and partial response were achieved in the majority of patients $(9.4 \%$ and $43.8 \%$, respectively), with only $9.4 \%$ showing disease progression. No grade 3/4 nephrotoxicity or neuropathy, both key toxicities of cisplatin, was noted.

Onivyde $^{\circledR}$ is an FDA-approved (2015) nanoliposomal formulation of irinotecan. ${ }^{42}$ Its official indication is for metastatic pancreatic cancer. In a Phase III trial on patients with gemcitabine-based chemotherapy-resistant metastatic pancreatic cancer, Onivyde plus 5-fluorouracil/leucovorin was significantly better than 5-fluorouracil/leucovorin only in terms of several clinical parameters. ${ }^{43}$ Irinotecan is not a commonly used drug for breast cancer; however, in a Phase I study with advanced refractory solid tumors that include breast cancer, the disease control rate with Onivyde was $45.5 \% .{ }^{44}$ All studies showed that it is well tolerated.

Besides these two products, there are other promising anticancer nanoformulations that have entered clinical phase. One example is Genexol-PM that is being developed by Samyang Biopharm in Korea. ${ }^{45}$ Genexol-PM is a solvent-free formulation of paclitaxel delivered by polymeric micelles made of their proprietary poly(ethylene glycol)-poly(lactic acid) block copolymers. In the Phase I and II trials on metastatic or recurrent breast cancer, it was reported that a higher maximal tolerable dose can be used, with $12.2 \%$ complete response and $46.3 \%$ partial response. ${ }^{46}$ An ongoing Phase III trial is being conducted in Korea now.

Overall, like Doxil and Abraxane, these nanoformulations are more generic anticancer products. In many nanotherapies described in the next section, researchers have begun to tailor the nanocarriers based on the characteristics of breast cancer.

\section{Latest trend for the development of nanomedicine-based breast cancer treatment Passive cancer targeting}

Materials of small size can preferentially accumulate in tumors over normal tissues because of the leaky vasculature and poorly developed lymphatic drainage in tumor tissues. This passive targeting effect is known as EPR.${ }^{47} \mathrm{EPR}$ can enhance the drug delivery specificity for solid malignant diseases such as breast cancer. Depending on the formulation, the enhancement can be quite significant. For instance, in specimens from human biopsies $20 \mathrm{~h}$ post-infusion of Lipoplatin, which has no active targeting feature, 40- to 200fold higher platinum concentration compared to the adjacent normal tissue was demonstrated..$^{38}$

In addition to EPR, nanocarriers may further improve the anticancer effect of their loaded drug at a cellular level. Even without involving specific receptor-mediated activities, a nanocarrier can enter cancer cells by passive endocytosis mechanisms such as macropinocytosis to potentiate the efficacy of drugs that act on intracellular targets (eg, RNA drugs, paclitaxel, doxorubicin). ${ }^{48}$

Overall, even though passive targeting is generally not a highly specific and efficient drug delivery approach, it should not be ignored in the discussion of the latest nanomedicine research because of its simplicity. There is no need for 
complicated modifications and inclusion of additional targeting moieties, so the risk of undesirable immunogenicity is reduced, and industrial upscaling and clinical translation become more likely. In fact, quite a number of recently developed breast cancer nanotherapies still rely on passive targeting. ${ }^{49-52}$

\section{Active targeting directly on breast cancer cells}

Active targeting is desired for higher cancer specificity and delivery efficiency. Targets may include the cancer cells and/or the TME. Nanocarriers are decorated with targeting moieties (eg, monoclonal antibodies or receptor ligands) with high affinities for these targets, so that the nanocarriers can bind and accumulate there. An ideal molecular target should fulfill the following parameters: 1) it should express at a relatively higher level in the cancer or TME than in the normal tissues; 2) its absolute level should also be high to enable efficient targeting; 3 ) it should be expressed at locations that are easily accessible by the nanocarriers, for example, surface receptor instead of intracellular receptor; 4) its expression level is preferably correlated with the malignant behaviors, such as aggressiveness or drug resistance, so these tough cancers can be targeted at a high priority and 5) targeting may facilitate events that promote the drug delivery process, for example, endocytosis of nanocarriers into cancer cells and transcytosis of nanocarriers across the tumor vasculature. In reality, only limited number of targets fulfill all or most of these criteria. In the next section, we will first discuss direct targeting of the key categories of cancer cells.

\section{Targeting breast cancer overexpressing human epidermal receptor 2}

About 25\%-30\% of breast cancers are HER2+, and HER2+ cancers tend to progress faster than most breast cancers, except triple-negative subtype. ${ }^{53}$ As HER2 is involved in activating several tumorigenesis pathways by dimerizing with other erbB receptors, HER2 monoclonal antibodies such as trastuzumab can be directly used to treat HER2+ breast cancer with significant benefit reported. ${ }^{54}$ For nanodelivery, the antibody can be used to decorate the nanocarrier surface to allow targeted delivery to HER2+ cells. Table 4 summarizes a number of recent studies on HER2-targeted nanomedicine. ${ }^{55-59}$ Although HER2 antibody is a targeting moiety commonly used for HER2+ cancer, other HER2 targeting ligands have also been studied. For instance, Ding et al used trastuzumab-mimetic peptide with promising results, and suggested that this may reduce the immunogenicity, production costs and technical efforts associated with the antibody. ${ }^{55}$ Recently, HER2 targeting has also been used for nonstandard drugs. The nanoparticles of Day et al and Cai et al both are decorated with trastuzumab for targeted photoablation therapy and radiation therapy. ${ }^{57,59}$

\section{Targeting TNBC}

Breast cancer that is estrogen receptor negative, progesterone receptor negative and HER2 negative is known as TNBC. About $15 \%-20 \%$ of breast cancer cases are TNBC. ${ }^{60}$ This fairly common breast cancer subtype is particularly difficult to treat and more deadly for several reasons. It is considered

Table 4 Nanomedicine for treatment of HER2-positive breast cancer

\begin{tabular}{|c|c|c|c|}
\hline Nanocarrier & Therapeutic agent(s) & Key outcomes & Reference \\
\hline Polymalic acid-based mini nanodrug & Antisense oligonucleotides & $\begin{array}{l}\text { HER2+ cells recognized by the polymer-attached } \\
\text { trastuzumab-mimetic } 12 \text {-mer peptide. HER2/neu } \\
\text { receptors downregulated, leading to reduced tumor size } \\
\text { by more than } 15 \text { times versus control }\end{array}$ & Ding et $\mathrm{al}^{55}$ \\
\hline $\begin{array}{l}\text { Ethylenediamine functionalized } \\
\text { single-walled nanotube }\end{array}$ & Oncogene suppressor $\mathrm{p} 53$ & $\begin{array}{l}\text { Increased uptake by MCF-7 cells, leading to enhanced } \\
\text { caspase-3-induced apoptosis }\end{array}$ & Karmakar et $\mathrm{al}^{56}$ \\
\hline $\begin{array}{l}\text { Combinational system of HER2 } \\
\text { immunoliposomes/liposomes }\end{array}$ & $\begin{array}{l}\text { Bevacizumab in } \\
\text { liposome; doxorubicin in } \\
\text { immunoliposome }\end{array}$ & $\begin{array}{l}\text { Combination achieved the best growth inhibition in } \\
\text { HER2/MDR double-positive breast cancer and the lowest } \\
\text { toxicity. Tumor size decreased steadily within } 60 \text { days }\end{array}$ & Tang et $\mathrm{al}^{58}$ \\
\hline $\begin{array}{l}\text { HER } 2 \text { antibody-conjugated } \\
\text { gold-gold sulfide nanoparticles }\end{array}$ & $\begin{array}{l}\text { Gold-gold sulfide for high- } \\
\text { intensity photoablation }\end{array}$ & $\begin{array}{l}\text { Nanoparticles can specifically bind SK-BR-3 cells } \\
\text { overexpressing HER2, inducing thermal damage to cancer } \\
\text { cells within seconds }\end{array}$ & Day et $\mathrm{al}^{57}$ \\
\hline $\begin{array}{l}\text { I I I-In-labeled trastuzumab- } \\
\text { modified gold nanoparticles }\end{array}$ & Radioactive I I I-In & $\begin{array}{l}\text { Local it injection to mice with sc MDA-MB-36I tumors } \\
\text { arrested tumor growth for } 70 \text { days with no apparent } \\
\text { normal tissue toxicity. The radiation absorbed dose } \\
\text { deposited in the tumor was } 60.5 \mathrm{~Gy} \text {, while normal organs } \\
\text { received }<0.9 \mathrm{~Gy}\end{array}$ & Cai et $\mathrm{al}^{59}$ \\
\hline
\end{tabular}

Abbreviations: HER2, human epidermal receptor 2; it, intrathecal; sc, subcutaneous; MDR, multidrug resistance. 
the most aggressive form of breast cancer and has higher incidence of BRCA-1 mutations. Its aggressiveness means when it is diagnosed, it is more often in advanced stage. ${ }^{60,61}$ Without the expression of those three receptors, TNBC is not sensitive to hormone therapy and anti-HER2 therapy. Chemotherapy becomes the only useful drug therapy, but about $60 \%$ TNBC cases were found to be chemoresistant. ${ }^{60,61}$

Besides HER2, several other molecular targets have been studied for active targeting of TNBC. EGFR is overexpressed in up to half of the TNBC cases and has a high density on the cell surface. ${ }^{62}$ Table 5 shows studies of nanodelivery to TNBC, including the use of anti-EGFR peptide, aptamer and monoclonal antibody. All of them indicate good cellular uptake by the TNBC cells and good efficacy in vitro and in vivo. ${ }^{64,65}$ Overall, EGFR is a promising target for nanotherapy of TNBC.

Folate receptor is also commonly targeted for nanodelivery because folate receptor is expressed in $50 \%-86 \%$ of metastatic TNBC patients and these patients generally have poorer prognosis (Table 5). ${ }^{66}$ There is concern that folate receptor is also expressed in normal tissues, but it is argued that nanodelivery to these tissues should be limited as the receptor is restricted to the lungs, kidneys, placenta and choroid plexus, and in these tissues, the receptor is limited to the apical surface which is poorly accessible. ${ }^{69}$ Other than folate receptor, $\mathrm{C}-\mathrm{X}-\mathrm{C}$ chemokine receptor type 4 is a potentially useful TNBC cell target, as it is often highly expressed in TNBC cells. ${ }^{70}$ The biggest appeal of this target is that its expression is associated with high risk of TNBC metastasis. ${ }^{70}$
Targeting C-X-C chemokine receptor type 4 may thus potentially control metastasis, as indicated in Table $5 .^{71,72}$

\section{Nanotherapy of breast cancer stem cells (BCSCs)}

It is suggested that a small fraction of cancer cells have the capacity for self-renewal and differentiation to multiple cancer cell types. They are often termed as cancer stem cells or tumor initiating cells. ${ }^{73}$ As long as these cells survive the anticancer treatment, they may serve as the "seeds" to enable the formation of a full tumor (ie, tumorigenic). In addition, accumulating evidence indicates that these cells are highly aggressive, have strong metastatic potential and are generally more drug resistant. ${ }^{73}$ It is, therefore, promising to prevent cancer relapse and metastasis by targeting these cells with nanomedicine.

BCSCs actually do not have many well-characterized biomarkers for targeting. CD44 receptor is by far the most popular because it is highly expressed on BCSC and also serves as a crucial signaling platform for the integration of the cues (eg, growth factors and cytokines) from the TME. ${ }^{74}$ A number of nanodelivery systems have been developed to target CD44 receptor using different targeting moieties (Table 6). ${ }^{75-78}$ Besides anti-CD44 monoclonal antibodies, hyaluronic acid is also a popular ligand for CD44 targeting, as CD44 is a receptor of hyaluronic acid. ${ }^{74}$ Other valuable targets of BCSC include CD133. CD133 ${ }^{+}$status was shown to correlate with overall survival and other clinical parameters in patients with breast cancer, including TNBC. ${ }^{79}$ Swaminathan

Table 5 Nanomedicine for treatment of triple-negative breast cancer

\begin{tabular}{|c|c|c|c|c|}
\hline Target & Nanocarrier & Therapeutic agent(s) & Key outcomes & Reference \\
\hline \multirow[t]{4}{*}{ EGFR } & $\begin{array}{l}\mathrm{pH} / \text { redox dual-sensitive } \\
\text { cationic unimolecular NP }\end{array}$ & siRNA & $\begin{array}{l}\text { GEI I peptide, an anti-EGFR peptide, was } \\
\text { found to significantly enhance the cellular } \\
\text { uptake of NPs in MDA-MB- } 468 \text { TNBC cells }\end{array}$ & Chen et $\mathrm{al}^{63}$ \\
\hline & RNA-NPs decorated with & Anti-miRNA & Strong accumulation of the NPs in orthotopic & Shu et $\mathrm{al}^{64}$ \\
\hline & EGFR-targeting aptamer & & $\begin{array}{l}\text { TNBC tumor model with reduced renal and } \\
\text { liver clearance was observed }\end{array}$ & \\
\hline & $\begin{array}{l}\text { Immunoliposomes decorated } \\
\text { with anti-EGFR antibody }\end{array}$ & Doxorubicin & $\begin{array}{l}\text { Phase I study indicated good tolerability and } \\
\text { recorded clinical activity }\end{array}$ & Mamot et $\mathrm{al}^{65}$ \\
\hline \multirow[t]{2}{*}{ Folate receptor } & $\begin{array}{l}\text { Micelles of copolymer } \\
\text { functionalized with folate }\end{array}$ & Orlistat & $\begin{array}{l}\text { In vitro and in vivo anticancer activities } \\
\text { through PARP inhibition reported }\end{array}$ & Paulmurugan et $\mathrm{al}^{67}$ \\
\hline & Folate-conjugated liposomes & Benzoporphyrin derivative & $\begin{array}{l}\text { Monolayer and 3-dimensional MDA-MB-23I } \\
\text { cell model was more responsive to the } \\
\text { targeted formulation }\end{array}$ & Sneider et $\mathrm{al}^{68}$ \\
\hline \multirow[t]{2}{*}{ CXCR4 } & $\begin{array}{l}\text { pH-sensitive immunoliposome } \\
\text { conjugated with anti-CXCR4 } \\
\text { antibody }\end{array}$ & $\begin{array}{l}\text { siRNA silencing oncoprotein } \\
\text { lipocalin-2 }\end{array}$ & $\begin{array}{l}\text { Significant lipocalin- } 2 \text { knockdown and } \\
\text { reduction in cell migration reported }\end{array}$ & Guo et $\mathrm{al}^{71}$ \\
\hline & $\begin{array}{l}\text { Nanostructured lipid carriers } \\
\text { (AMD3 I00 coated as } \\
\text { targeting ligands) }\end{array}$ & $\begin{array}{l}\text { CXCR4 antagonist AMD3I } 00 \\
\text { and photothermal therapy } \\
\text { agent IR780 }\end{array}$ & $\begin{array}{l}\text { Able to reduce TNBC metastasis and achieve } \\
\text { improved photothermal therapy at the } \\
\text { same time }\end{array}$ & Li et $\mathrm{al}^{72}$ \\
\hline
\end{tabular}

Abbreviations: EGFR, epidermal growth factor receptor; NPs, nanoparticles; PARP, Poly (ADP-ribose) polymerase; TNBC, triple-negative breast cancer. 
Table 6 Nanomedicine for breast cancer stem cell therapy

\begin{tabular}{|c|c|c|c|c|}
\hline Target & Nanocarrier & $\begin{array}{l}\text { Therapeutic } \\
\text { agent(s) }\end{array}$ & Key outcomes & Reference \\
\hline \multirow[t]{4}{*}{ CD44 } & $\begin{array}{l}\text { PLGA-co-PEG micelles decorated } \\
\text { with anti-CD44 antibodies }\end{array}$ & Paclitaxel & $\begin{array}{l}\text { Using a new fluorescent cancer cell model, they } \\
\text { were able to demonstrate improved sensitivity of } \\
\text { cancer stem cells to paclitaxel }\end{array}$ & Gener et $\mathrm{al}^{75}$ \\
\hline & $\begin{array}{l}\text { PLGA nanoparticles coated with } \\
\text { hyaluronic acid }\end{array}$ & $\begin{array}{l}\text { Salinomycin and } \\
\text { paclitaxel }\end{array}$ & $\begin{array}{l}\text { Surface coating of hyaluronic acid led to a } 1.5 \text {-fold } \\
\text { increase in uptake into the CD } 44^{+} \text {MDA-MB- } 23 \text { I } \\
\text { cells and highest in vitro activity }\end{array}$ & Muntimadugu et $\mathrm{a}^{76}$ \\
\hline & $\begin{array}{l}\text { Chitosan-decorated Pluronic FI } 27 \\
\text { nanoparticles }\end{array}$ & Doxorubicin & $\begin{array}{l}\text { Significant improvement in doxorubicin delivery to } \\
\text { CD } 44^{+} \text {cells was reported with strong cytotoxicity }\end{array}$ & Rao et $\mathrm{al}^{77}$ \\
\hline & $\begin{array}{l}\text { Nanoparticles consist of four } \\
\text { polymers PLGA Pluronic FI } 27 \text {, } \\
\text { chitosan and hyaluronic acid }\end{array}$ & $\begin{array}{l}\text { Doxorubicin and } \\
\text { irinotecan }\end{array}$ & $\begin{array}{l}\text { Nanoparticles effective in cancer stem cells in vitro } \\
\text { and in vivo, with up to } \sim 500 \text { times of enhancement } \\
\text { versus simple mixture of two drugs }\end{array}$ & Wang et $\mathrm{al}^{78}$ \\
\hline CDI33 & $\begin{array}{l}\text { PLGA nanoparticles decorated } \\
\text { with anti-CDI33 antibody }\end{array}$ & Paclitaxel & $\begin{array}{l}\text { Effective in decreasing the number of MDA-MB- } 23 \text { I } \\
\text { mammospheres and colonies that are refractory to } \\
\text { paclitaxel }\end{array}$ & Swaminathan et $\mathrm{al}^{80}$ \\
\hline CD44+ DCLKI & $\begin{array}{l}\text { PLGA-PEG nanoparticles dual } \\
\text { grafted with hyaluronic acid and } \\
\text { DCLKI antibody }\end{array}$ & No drug & $\begin{array}{l}\text { Dual-grafted nanoparticles exhibited a targeting } \\
\text { effect toward CSCs in vitro and in vivo stronger } \\
\text { than when only one targeting moiety was used }\end{array}$ & Qiao et $a^{82}$ \\
\hline
\end{tabular}

Abbreviations: CSC, cancer stem cells; PEG, polyethylene glycol; PLGA, poly (lactic-co-glycolic acid).

et al developed PLGA nanoparticles decorated with antiCD133 antibody for paclitaxel delivery. ${ }^{80}$ Interestingly, this study showed that while free paclitaxel effectively inhibited tumor growth at the beginning, the tumors rebounded quickly once the treatment was discontinued; whereas no such problem was encountered with the CD133-targeted nanoparticles. The study demonstrated that the key benefit of cancer stem cell nanodelivery may actually be preventing breast cancer recurrence, which is critical in breast cancer treatment.

One key factor that makes BCSC targeting difficult is that BCSCs often enter dormant state and their population is low. ${ }^{81}$ One recent strategy proposed to achieve improved BCSC targeting is through dual targeting. Qiao et al showed that the hyaluronic acid and DCLK1 antibody dual-decorated nanoparticles target the mammospheres better than single-targeted system. ${ }^{82}$ This may be an interesting strategy that could be investigated further.

\section{TME-based nanotherapy}

Instead of targeting cancer cells directly, some researchers choose a less direct approach by targeting the TME instead. ${ }^{83}$ From the nanodelivery perspective, the TME is moderately more acidic (pH 6.5-6.9, as low as 5) and more hypoxic than the normal tissue, and these properties can be exploited for nanodelivery. ${ }^{83}$ Moreover, in recent years, the impact of the TME on cancer progression and metastasis has been increasingly elucidated. Targeting the TME may interfere in its interactions with the cancer cells to achieve effective treatment. ${ }^{84}$ Till date, several strategies have been studied for nanodelivery to breast cancer TME. These include $\mathrm{pH}-$ responsive delivery, targeting hypoxia, targeting TAMs and targeting other TME components.

\section{$\mathrm{pH}$-responsive drug delivery}

The acidic TME can be exploited to achieve stimulusresponsive nanodelivery by designing nanocarriers that are hydrolyzable at low $\mathrm{pH}$ to release their loaded drugs. Besides increasing intratumoral drug level, this strategy may also ensure faster intracellular drug release if the nanocarrier is internalized to the acidic lysosomal content. Several $\mathrm{pH}-$ responsive nanodelivery systems were, therefore, developed for breast cancer treatment (Table 7A) ${ }^{85-89}$ In general, drug release was all faster at lower $\mathrm{pH}$ due to acid hydrolysis of the linkages in the nanocarrier.

\section{Nanotherapy of hypoxia-related events}

Solid tumors such as breast cancer tend to have hypoxic microenvironment due to poor vascularization. The hypoxia can significantly increase the risk of cancer gene mutations and, hence, cancer progression and spreading. This microenvironment may also lead to the so-called "panchemoresistance" to a broad range of anticancer drugs..$^{90}$ Intervention of these complex, unfavorable events is very challenging. Drug compounds may hardly access and accumulate in the poorly vascularized TME in an efficient manner. The passive and active targeting effects of nanomedicine may improve the tumoral drug concentrations to better tackle selected hypoxia-related events for cancer treatment. 
Table 7 Tumor microenvironment-based nanotherapy: $\mathrm{pH}$-responsive nanocarriers

\begin{tabular}{|c|c|c|c|}
\hline Nanocarrier & $\begin{array}{l}\text { Therapeutic } \\
\text { agent(s) }\end{array}$ & Key outcomes & Reference \\
\hline \multicolumn{4}{|l|}{ A pH-responsive nanocarriers } \\
\hline $\begin{array}{l}\text { Micelles of amphiphilic copolymer joined by } \\
\beta \text {-thiopropionate linkage }\end{array}$ & Doxorubicin & $\begin{array}{l}\text { Linkage can undergo acid hydrolysis. Drug } \\
\text { release } 80 \% \text { at } \mathrm{pH} 5.2 \% \text { versus } 35 \% \text { at } \mathrm{pH} 7.4 \\
\text { after } 100 \text { hours }\end{array}$ & $\begin{array}{l}\text { Pramanik } \\
\text { et } \text { al }^{85}\end{array}$ \\
\hline Chitosan-based glycolipid-like nanocarrier & Doxorubicin & $\begin{array}{l}\text { More cytotoxic to MCF-7 breast cancer cells } \\
\text { than to SKOV } 3 \text { ovarian cancer cells because the } \\
\text { former cell line has more acidic extracellular } \\
\text { environment }\end{array}$ & $\begin{array}{l}\text { Cheng et } \\
\mathrm{al}^{86}\end{array}$ \\
\hline pH-responsive liposomes & Paclitaxel & $\begin{array}{l}\text { Faster paclitaxel release in acidic } \mathrm{pH} \text { and more } \\
\text { effective both in vitro and in vivo on breast } \\
\text { cancer models }\end{array}$ & Jiang et $\mathrm{a}^{87}$ \\
\hline $\begin{array}{l}\text { pH-responsive triblock copolymeric micelles with cell- } \\
\text { pentetrating peptides }\end{array}$ & Doxorubicin & $\begin{array}{l}\text { Doxorubicin release was } \mathrm{pH} \text { dependent, about } \\
65 \% \text { released at } \mathrm{pH} 5.0 \text { and } 32 \% \text { at } \mathrm{pH} 7.4 \text {. More } \\
\text { cytotoxic than free doxorubicin on breast cancer } \\
\text { cells }\end{array}$ & $\mathrm{Ng}$ et al ${ }^{88}$ \\
\hline $\begin{array}{l}\text { Acidity-sensitive linkage-bridged block copolymer } \\
\text { nanoparticles }\end{array}$ & siRNA & $\begin{array}{l}\text { PEG surface layer detached in response to tumor } \\
\text { acidity to facilitate cellular uptake, and siRNA } \\
\text { rapidly released within tumor cells due to the } \\
\text { hydrophobic PLGA layer }\end{array}$ & Xu et $a^{89}$ \\
\hline \multicolumn{4}{|l|}{ B Targeting of tumor-associated macrophages } \\
\hline Abraxane & Paclitaxel & $\begin{array}{l}\text { In addition to EPR and gP60 targeting, Abraxane } \\
\text { may increase the CD } 80^{+} C D 86^{+} \mathrm{MI} \text { macrophage } \\
\text { subpopulation and work against } \mathrm{M} 2 \text { cells to } \\
\text { provide additional anticancer effects }\end{array}$ & $\begin{array}{l}\text { Cullis } \\
\text { et al }{ }^{95}\end{array}$ \\
\hline Legumain-targeting liposomal nanoparticles & Hydrazinocurcumin & $\begin{array}{l}\text { By inhibiting the STAT3 activity of TAM, TAM } \\
\text { got "re-educated" and switched to MI-like } \\
\text { macrophages, leading to inhibition of } 4 \text { TI cell } \\
\text { migration and invasion in vitro and suppression of } \\
\text { tumor growth, angiogenesis and metastasis in vivo }\end{array}$ & $\begin{array}{l}\text { Zhang } \\
\text { et } \mathrm{al}^{96}\end{array}$ \\
\hline PLGA nanoparticles with mannose & Doxorubicin & $\begin{array}{l}\text { Significantly improve the anticancer effect of the } \\
\text { nanoparticles in triple-negative breast cancer, } \\
\text { indicating depletion of TAM }\end{array}$ & Niu et $\mathrm{al}^{97}$ \\
\hline
\end{tabular}

\begin{tabular}{|c|c|c|c|c|}
\hline \multicolumn{5}{|c|}{ C Targeting other targets in tumor microenvironment } \\
\hline Target & Nanocarrier & $\begin{array}{l}\text { Therapeutic } \\
\text { agent(s) }\end{array}$ & Key outcomes & Reference \\
\hline \multirow[t]{2}{*}{ Stromal cells } & $\begin{array}{l}\text { Liposomes decorated with } \\
\text { lipidated cathepsin B inhibitor }\end{array}$ & NS629 & $\begin{array}{l}\text { By targeting cathepsin B, selective targeting and } \\
\text { internalization of liposomes observed, leading } \\
\text { to enhanced delivery ex vivo and in vivo in an } \\
\text { orthotopic breast cancer model }\end{array}$ & $\begin{array}{l}\text { Mikhaylov } \\
\text { et al99 }\end{array}$ \\
\hline & $\begin{array}{l}\text { Cellax }{ }^{\circledR} \text { (nanoparticles of acetylated } \\
\text { carboxymethylcellulose linked with } \\
\text { PEG) }\end{array}$ & Docetaxel & $\begin{array}{l}\text { Reported higher MTD and lower tumor growth } \\
\text { and metastasis than Abraxane in multiple } \\
\text { xenograft models; also, decreased } \alpha \text {-smooth } \\
\text { muscle actin content in } 4 \text { TI and MDA-MB- } 23 \text { I } \\
\text { model by } 82 \% \text { and } 70 \% \text {, respectively }\end{array}$ & $\begin{array}{l}\text { Ernsting } \\
\text { et al; ;00 } \\
\text { Murakami } \\
\text { et al }{ }^{101}\end{array}$ \\
\hline MMP-9 & $\begin{array}{l}\text { Liposome with degradable } \\
\text { lipopeptides }\end{array}$ & $\begin{array}{l}\text { Carboxyfluorescein } \\
\text { as fluorescent dye }\end{array}$ & $\begin{array}{l}\text { Lipopeptide degraded by MMP- } 9 \text {, substantial } \\
\text { increase in release rate in the presence of MMP- } 9\end{array}$ & $\begin{array}{l}\text { Banerjee } \\
\text { et al }{ }^{103}\end{array}$ \\
\hline MMP-2 & $\begin{array}{l}\text { Liposome modified with } \\
\text { chlorotoxin }\end{array}$ & Doxorubicin & $\begin{array}{l}\text { Chlorotoxin-modified liposomes exhibited higher } \\
\text { in vitro toxicity and in vivo targeting efficiency to } \\
4 \mathrm{TI} \text { tumors than nonmodified liposomes, and could } \\
\text { prevent lung metastasis with low systemic toxicity }\end{array}$ & Qin et al ${ }^{104}$ \\
\hline $\begin{array}{l}\text { FSH receptor on } \\
\text { tumor vasculature }\end{array}$ & $\begin{array}{l}\text { Nano-graphene oxide with FSH } \\
\text { antibody }\end{array}$ & Doxorubicin & $\begin{array}{l}\text { Vasculature accumulation of GO-FSHR-mAb } \\
\text { conjugates in tumor at early time points; } \\
\text { enhanced drug delivery efficiency in MDA-MB- } \\
23 \text { I metastatic sites }\end{array}$ & $\begin{array}{l}\text { Yang } \\
\text { et al }{ }^{105}\end{array}$ \\
\hline
\end{tabular}

Abbreviations: EPR, enhanced permeability and retention; FSH, follicle stimulating hormone; MMP, matrix metalloproteinase; MTD, maximum tolerable dose; PEG, polyethylene glycol; PLGA, poly (lactic-co-glycolic acid); STAT3, Signal transducer and activator of transcription 3; TAMs, tumor-associated macrophages. 
For instance, liposome of disulfiram was developed to reverse pan-chemoresistance caused by hypoxia-induced nuclear factor-кB. ${ }^{91}$ The study showed that liposomal disulfiram was effective in disrupting the nuclear factor- $\kappa B$ pathway in spheroid cultured breast cancer cell model manifesting cancer stem cell characteristics and pan-chemoresistance, and this translated into significant in vitro and in vivo efficacy. In another series of studies of CRLX101, ${ }^{92}$ an investigational nanoparticle-drug conjugate with a camptothecin payload, the nanoformulation was evaluated alone or in combination with antiangiogenic drugs such as bevacizumab in murine breast cancer model. Tumors tend to develop resistance to antiangiogenic drugs by upregulation of hypoxia-inducible factor- $1 \alpha$. This can be blocked with camptothecin, but this compound is very poorly soluble and causes strong systemic toxicity. These issues can be addressed by delivering the drug as nanoformulation CRLX101. It was found effective in durably blocking the hypoxia-inducible factor- $1 \alpha$, restoring the cancer sensitivity to bevacizumab, improving tumor perfusion and reducing hypoxia. ${ }^{93}$

\section{Nanotherapy of TAM}

There are several subtypes of macrophages in TME and they are promising targets. ${ }^{94} \mathrm{M} 1$ macrophages are known to be involved in inflammatory processes and may have significant antitumor effects. On the contrary, activated M2 macrophages, which are generally involved in the wound-healing events in tumors, may behave antagonistically to M1 as TAM. ${ }^{94}$ TAMs play instrumental roles in various processes such as matrix modeling, neoangiogenesis and local immunity suppression that facilitate cancer growth, invasion and spreading. They have been targeted with nanodelivery systems to achieve TAM reprogramming, suppression, depletion and recruitment prevention.

Table 7B lists the nanodelivery systems that may achieve anticancer effects via macrophages. ${ }^{95-97}$ Interestingly, it was found that a part of Abraxane's activity may be derived from its activity in increasing the $\mathrm{CD} 80^{+} \mathrm{CD} 86^{+} \mathrm{M} 1$ macrophage subpopulation that works in an antagonistic manner to the M2 subpopulation. ${ }^{95}$ Regardless, macrophage-based nanotherapy remains in exploratory stage and more studies are needed to substantiate its potential.

\section{Other promising targets in TME}

Stromal cells are connective tissue cells such as fibroblasts and pericytes. They were long shown to play crucial roles in mammary gland development and breast cancer progression. ${ }^{98}$ Their activities can be interfered for breast cancer treatment with nanotherapeutics (Table 7C).${ }^{99-101}$ Cellax is a nanoparticle made of acetylated carboxymethylcellulose-PEG for docetaxel delivery. ${ }^{100}$ It has been clinically evaluated for breast cancer treatment, and is claimed to be superior to Abraxane in many aspects including reduced tumor growth and metastasis. What is appealing is that Cellax was found to decrease $\alpha$-smooth muscle actin content by $82 \%$ and $70 \%$, respectively, versus no significant change in free docetaxel and Abraxane groups. The reduction in smooth muscle actin by Cellax contributed to substantial increase in tumor perfusion and tumor vascular permeability and reduction in tumor matrix and interstitial pressure versus control. ${ }^{102}$ It will be interesting to see if these outcomes are translatable in clinical setting.

There are other valuable targets in the TME such as MMPs. MMP-9 is a MMP subtype highly expressed in metastatic breast tumors. The protease activity of MMP-9 was heavily involved in extracellular matrix remodeling and angigogenesis in TME, and can be exploited for triggering drug release. ${ }^{103}$ MMP-2 is another potential MMP target associated with advanced breast cancer. ${ }^{104}$ In addition, it is also possible to target tumor vasculature to enhance tumoral drug delivery. ${ }^{105}$

\section{Nanotherapy to tackle drug-resistant breast cancer}

Drug resistance is one of the biggest obstacles in breast cancer treatment. It is a highly complex phenomenon contributed by multiple mechanisms including P-glycoprotein overexpression, mutations in drug-binding sites such as microtubule, mutations of genes, HER2 overexpression and many more. ${ }^{106,107}$ Many nanocarriers can partly solve some of these issues by bypassing the cell membrane barrier via endocytosis and achieve high intracellular drug concentration even with only passive targeting. ${ }^{48}$

Another popular strategy to tackle this issue is using combination therapy. Typically, this includes one or more cytotoxic chemotherapy agents and a novel "helper" that either interferes with a drug resistance pathway or controls a specific cell population that enhances drug resistance. A previous mechanistic study has demonstrated that for this type of combination, co-delivery was most effective because both drugs can simultaneously reach the same site of the same cell to maximize the synergistic or additive effects. ${ }^{108}$ Table 8 lists some recent co-delivery nanoformulations. ${ }^{109-113}$ All demonstrate better efficacy than cytotoxic monotherapy.

\section{Conclusion}

With better understanding of the molecular biology of breast cancer, substantial progress has been made in recent years in 
Table 8 Co-delivery strategy: nanocarriers simultaneously delivering two therapeutic agents for enhanced anticancer effects

\begin{tabular}{|c|c|c|c|}
\hline Nanocarrier & Therapeutic agent(s) & Key outcomes & Reference \\
\hline PLGA nanoparticles & $\begin{array}{l}\text { Rapamycin as chemotherapy } \\
\text { agent; piperine as chemosensitizer }\end{array}$ & $\begin{array}{l}\text { Uptake of rapamycin (a P-glycoprotein substrate) into breast } \\
\text { cancer cells improved with piperine; bioavailability increased } \\
4.8 \text {-fold as well }\end{array}$ & Katiyar et al ${ }^{109}$ \\
\hline $\begin{array}{l}\text { Folate-conjugated } \\
\text { lipid nanoparticles }\end{array}$ & $\begin{array}{l}\text { Paclitaxel for chemotherapy; } \\
\text { curcumin }\end{array}$ & Increased uptake of paclitaxel and curcumin into MCF-7/ADR cells & Baek and $\mathrm{Cho}{ }^{110}$ \\
\hline Cationic peptide & $\begin{array}{l}\text { Doxorubicin for chemotherapy; } \\
\text { PTRAIL as chemosensitizer }\end{array}$ & $\begin{array}{l}\text { Increased cellular apoptosis by } 83.7 \% \text { in MCF-7/ADR cells; with } \\
\text { a tumor inhibitory rate of } 94.0 \% \text {; synergistic effect reported }\end{array}$ & Hu et al'"l \\
\hline PLGA nanoparticle & $\begin{array}{l}\text { Doxorubicin for chemotherapy; } \\
\text { resveratrol to help }\end{array}$ & $\begin{array}{l}\text { Inhibited expression of } \mathrm{P} \text {-glycoprotein, } \mathrm{MrP}-\mathrm{I}, \mathrm{BCRP} \text { and induced } \\
\text { apoptosis by downregulating nuclear factor- } \mathrm{KB} \text { and } \mathrm{BCL}-2 \\
\text { expression; significant in vivo tumor growth inhibition with } \\
\text { minimal toxicity }\end{array}$ & Zhao et al ${ }^{1 / 2}$ \\
\hline Liposomes & $\begin{array}{l}\text { Doxorubicin for chemotherapy; } \\
\text { chloroquine as autophagy inhibitor }\end{array}$ & $\begin{array}{l}I_{50} \text { in MCF-7/ADR cells reduced by } 5.7 \text {-fold compared with free } \\
\text { doxorubicin; exerted better antitumor effects in spheroid model } \\
\text { and transgenic zebrafish model than liposomal doxorubicin } \\
\text { or doxorubicin alone }\end{array}$ & Gao et $\mathrm{al}^{113}$ \\
\hline
\end{tabular}

Abbreviations: PLGA, poly (lactic-co-glycolic acid); PTRAIL, TNF-related apoptosis-inducing ligand protein.

using nanomedicine for breast cancer treatment. It is expected that using the previously discussed new strategies, more products will enter clinical phase with success.

However, caution must be exercised in adopting these advanced strategies. The biggest issue is about the increased complexity of the nanoformulation. For instance, most of the recent nanotherapeutic strategies for breast cancer treatment are based on active targeting. While this is theoretically superior to passive targeting, inclusion of targeting moieties also means increased formulation complexity, which translates into increased risk of toxicity and immunogenicity, higher production cost, and potential upscalability and good manufacturing practice issues. This issue is also applicable to the multidrug nanoformulations. The researchers need to provide sufficient evidence demonstrating that the more complex nanoformulations are clinically more effective, sufficiently stable and cost-effective.

Finally, it should be noted that breast cancer is most deadly and toughest to treat when metastasis occurs. Breast cancer tends to spread to the bone, lung, liver and brain, but many of these sites are not easily accessible by the majority of anticancer therapeutics including nanoformulations. Designing nanoformulations that can adequately penetrate all of these sites without causing excessive adverse effects is of critical importance. It is expected that strong collaboration with experts in pharmacokinetics, toxicology, immunology and oncology will become essential in future development of breast cancer nanomedicine.

\section{Abbreviations}

BCSCs, breast cancer stem cells; CXCR4, C-X-C chemokine receptor type 4; EGFR, epidermal growth factor receptor;
EPR, enhanced permeability and retention; HER2, human epidermal receptor 2; MMP, matrix metalloproteinase; PEG, polyethylene glycol; PLGA, poly (lactic-coglycolic acid); TAMs, tumor-associated macrophages; TME, tumor microenvironment; TNBC, triple-negative breast cancer.

\section{Acknowledgment}

This work was supported by the National Institutes of Health/ National Cancer Institute R01 grant (R01CA168917).

\section{Disclosure}

The authors report no conflicts of interest in this work.

\section{References}

1. DeSantis C, Ma J, Bryan L, Jemal A. Breast cancer statistics, 2013. CA Cancer J Clin. 2014;64(1):52-62.

2. Torre LA, Islami F, Siegel RL, Ward EM, Jemal A. Global cancer in women: burden and trends. Cancer Epidemiol Biomarkers Prev. 2017; 26(4):444-457.

3. Breastcancer.org. US Breast Cancer Statistics. Available from: http:// www.breastcancer.org/symptoms/understand_bc/statistics. Accessed May 18, 2017.

4. Sinn HP, Kreipe H. A brief overview of the WHO classification of breast tumors. Breast Care. 2013;8(2):149-154.

5. van Nijnatten T, Moossdorff M, de Munck L, et al. TNM classification and the need for revision of pN3a breast cancer. Eur J Cancer. 2017;79: 23-30.

6. Altekruse SF, Kosary CL, Krapcho M, et al. SEER cancer statistics review, 1975-2007. Bethesda, MD: National Cancer Institute. 2010;7. Available from: https://seer.cancer.gov/archive/csr/1975_2007/. Accessed May 17, 2017.

7. Weigelt B, Peterse JL, Van't Veer LJ. Breast cancer metastasis: markers and models. Nat Rev Cancer. 2005;5(8):591-602.

8. Park H, Chang SK, Kim JY, Lee BM, Shin HS. Risk factors for distant metastasis as a primary site of treatment failure in early-stage breast cancer. Chonnam Med J. 2014;50(3):96-101.

9. Arpino G, Milano M, De Placido S. Features of aggressive breast cancer. Breast. 2015;24(5):594-600. 
10. Zhang RX, Wong HL, Xue HY, Eoh JY, Wu XY. Nanomedicine of synergistic drug combinations for cancer therapy-Strategies and perspectives. J Control Release. 2016;240:489-503.

11. Xue HY, Liu S, Wong HL. Nanotoxicity: a key obstacle to clinical translation of siRNA-based nanomedicine. Nanomedicine (Lond). 2014;9(2):295-312.

12. nih.gov. US National Institute of Health, Nanomedicine, Nanomedicine Overview. Available from: https://commonfund.nih.gov/nanomedicine/ overview. Accessed May 17, 2017.

13. Greenlee H, DuPont Reyes MJ, Balneaves LG, et al. Clinical practice guidelines on the evidence-based use of integrative therapies during and after breast cancer treatment. CA Cancer J Clin. 2017;67(3): 194-232.

14. Masoud V, Pagès G. Targeted therapies in breast cancer: New challenges to fight against resistance. World J Clin Oncol. 2017;8(2): $120-134$.

15. Majidinia M, Yousefi B. Breast tumor stroma: a driving force in the development of resistance to therapies. Chem Biol Drug Des. 2017;89(3): 309-318.

16. Van de Wiel M, Dockx Y, Van den Wyngaert T, Stroobants S, Tjalma WA, Huizing MT. Neoadjuvant systemic therapy in breast cancer: Challenges and uncertainties. Eur J Obstet Gynecol Reprod Biol. 2017;210: 144-156.

17. Lee JJ, Yazan LS, Abdullah CA. A review on current nanomaterials and their drug conjugate for targeted breast cancer treatment. Int $J$ Nanomed. 2017;12:2373-2384.

18. Barenholz YC. Doxil-the first FDA-approved nano-drug: lessons learned. J Control Release. 2012;160(2):117-134.

19. Tacar O, Sriamornsak P, Dass CR. Doxorubicin: an update on anticancer molecular action, toxicity and novel drug delivery systems. J Pharm Pharmacol. 2013;65(2):157-170.

20. Chatterjee K, Zhang J, Honbo N, Karliner JS. Doxorubicin cardiomyopathy. Cardiology. 2010;115(2):155-162.

21. Vail DM, Amantea MA, Colbern GT, Martin FJ, Hilger RA, Working PK. Pegylated liposomal doxorubicin: proof of principle using preclinical animal models and pharmacokinetic studies. Semin Oncol. 2004;31(6 Suppl 13):16-35.

22. Tahover E, Patil YP, Gabizon AA. Emerging delivery systems to reduce doxorubicin cardiotoxicity and improve therapeutic index: focus on liposomes. Anticancer Drugs. 2015;26(3):241-258.

23. O'brien M, Wigler N, Inbar M, et al; CAELYX Breast Cancer Study Group. Reduced cardiotoxicity and comparable efficacy in a phase III trial of pegylated liposomal doxorubicin $\mathrm{HCl}\left(\mathrm{CAELYX}^{\mathrm{TM}} /\right.$ Doxil) versus conventional doxorubicin for first-line treatment of metastatic breast cancer. Ann Oncol. 2004;15(3):440-449.

24. Rau KM, Lin YC, Chen YY, et al. Pegylated liposomal doxorubicin $\left(\right.$ Lipo-Dox ${ }^{\circledR}$ ) combined with cyclophosphamide and 5-fluorouracil is effective and safe as salvage chemotherapy in taxane-treated metastatic breast cancer: an open-label, multi-center, non-comparative phase II study. BMC Cancer. 2015;15(1):423.

25. Torrisi R, Montagna E, Scarano E, et al. Neoadjuvant pegylated liposomal doxorubicin in combination with cisplatin and infusional fluoruracil (CCF) with and without endocrine therapy in locally advanced primary or recurrent breast cancer. Breast. 2011;20(1):34-38.

26. Gil-Gil MJ, Bellet M, Morales S, et al. Pegylated liposomal doxorubicin plus cyclophosphamide followed by paclitaxel as primary chemotherapy in elderly or cardiotoxicity-prone patients with high-risk breast cancer: results of the phase II CAPRICE study. Breast Cancer Res Treat. 2015; 151(3):597-606.

27. Torrisi R, Cardillo A, Cancello G, et al. Phase II trial of combination of pegylated liposomal doxorubicin, cisplatin, and infusional 5-fluorouracil (CCF) plus trastuzumab as preoperative treatment for locally advanced and inflammatory breast cancer. Clin Breast Cancer. 2010;10(6):483-488.

28. Ansari L, Shiehzadeh F, Taherzadeh Z, et al. The most prevalent side effects of pegylated liposomal doxorubicin monotherapy in women with metastatic breast cancer: a systematic review of clinical trials. Cancer Gene Therapy. 2017;24(5):189-193.
29. Minckwitz Von G, Martin M, Wilson G, et al. Optimizing taxane use in MBC in the emerging era of targeted chemotherapy. Crit Rev Oncol Hematol. 2013;85(3):315-331.

30. Li Y, Chen N, Palmisano M, Zhou S. Pharmacologic sensitivity of paclitaxel to its delivery vehicles drives distinct clinical outcomes of paclitaxel formulations. Mol Pharm. 2015;12(4):1308-1317.

31. Desai N, Trieu V, Yao Z, et al. Increased antitumor activity, intratumor paclitaxel concentrations, and endothelial cell transport of cremophorfree, albumin-bound paclitaxel, ABI-007, compared with cremophorbased paclitaxel. Clin Cancer Res. 2006;12(4):1317-1324.

32. Chen N, Li Y, Ye Y, Palmisano M, Chopra R, Zhou S. Pharmacokinetics and pharmacodynamics of nab-paclitaxel in patients with solid tumors: Disposition kinetics and pharmacology distinct from solvent-based paclitaxel. J Clin Pharmacol. 2014;54(10):1097-1107.

33. Gardner ER, Dahut WL, Scripture CD, et al. Randomized crossover pharmacokinetic study of solvent-based paclitaxel and nab-paclitaxel. Clin Cancer Res. 2008;14(13):4200-4205.

34. Untch M, Jackisch C, Schneeweiss A, et al; German Breast Group (GBG); Arbeitsgemeinschaft Gynäkologische Onkologie-Breast (AGO-B) Investigators. Nab-paclitaxel versus solvent-based paclitaxel in neoadjuvant chemotherapy for early breast cancer (GeparSepto-GBG 69): a randomized, phase 3 trial. Lancet Oncol. 2016;17(3):345-356.

35. Tezuka K, Takashima T, Kashiwagi S, et al. Phase I study of nanoparticle albumin-bound paclitaxel, carboplatin and trastuzumab in women with human epidermal growth factor receptor 2-overexpressing breast cancer. Mol Clin Oncol. 2017;6(4):534-538.

36. Nahleh ZA, Barlow WE, Hayes DF, et al. SWOG S0800 (NCI CDR0000636131): addition of bevacizumab to neoadjuvant nabpaclitaxel with dose-dense doxorubicin and cyclophosphamide improves pathologic complete response (pCR) rates in inflammatory or locally advanced breast cancer. Breast Cancer Res Treat. 2016;158(3):485-495.

37. Stathopoulos GP, Boulikas T. Lipoplatin formulation review article. J Drug Delivery. 2012;2012:581363.

38. Boulikas T, Stathopoulos GP, Volakakis N, Vougiouka M. Systemic Lipoplatin infusion results in preferential tumor uptake in human studies. Anticancer Res. 2005;25(4):3031-3039.

39. Jehn CF, Boulikas T, Kourvetaris A, Kofla G, Possinger K, Lüftner D. First safety and response results of a randomized phase III study with liposomal platin in the treatment of advanced squamous cell carcinoma of the head and neck (SCCHN). Anticancer Res. 2008;28(6B):3961-3964.

40. Ravaioli A, Papi M, Pasquini E, et al. Lipoplatin ${ }^{\mathrm{TM}}$ monotherapy: a phase II trial of second-line treatment of metastatic non-small-cell lung cancer. J Chemother. 2009;21(1):86-90.

41. Mylonakis N, Athanasiou A, Ziras N, et al. Phase II study of liposomal cisplatin (Lipoplatin) plus gemcitabine versus cisplatin plus gemcitabine as first line treatment in inoperable (stage IIIB/IV) non-small cell lung cancer. Lung Cancer. 2010;68(2):240-247.

42. Zhang H. Onivyde for the therapy of multiple solid tumors. Onco Targets Ther. 2016;9:3001-3007.

43. Hoff Von D, Li CP, Wang-Gillam A, et al. NAPOLI 1: Randomized phase 3 study of MM-398 (nal-IRI), with or without 5-fluorouracil and leucovorin, versus 5-fluorouracil and leucovorin, in metastatic pancreatic cancer progressed on or following gemcitabine-based therapy. Ann Oncol. 2014;25(2):105-106.

44. Chang TC, Shiah HS, Yang CH, et al. Phase I study of nanoliposomal irinotecan (PEP02) in advanced solid tumor patients. Cancer Chemother Pharmacol. 2015;75(3):579-586.

45. Samyang Biopharm, Genexol PM. Available from: https://www. samyangbiopharm.com/eng/ProductIntroduce/injection01. Accessed May 20, 2017.

46. Samyang Biopharmaceuticals Corporation. Genexol-PM(paclitaxel). Available from: https://www.samyangbiopharm.com/eng/ProductIntroduce/injection01. Accessed November 29, 2016.

47. Matsumura Y, Maeda H. A new concept for macromolecular therapeutics in cancer chemotherapy: mechanism of tumoritropic accumulation of proteins and the antitumor agent smancs. Cancer Res. 1986;46(12 Part 1): 6387-6392. 
48. Wong HL, Bendayan R, Rauth AM, Xue HY, Babakhanian K, Wu XY. A mechanistic study of enhanced doxorubicin uptake and retention in multidrug resistant breast cancer cells using a polymer-lipid hybrid nanoparticle system. J Pharmacol Exp Ther. 2006;317(3):1372-1381.

49. Kim SY, Hwang JY, Seo JW, Shin US. Production ofCNT-taxol-embedded PCL microspheres using an ammonium-based room temperature ionic liquid: As a sustained drug delivery system. J Colloid Interface Sci. 2015; 442:147-153.

50. Kang KW, Chun MK, Kim O, et al. Doxorubicin-loaded solid lipid nanoparticles to overcome multidrug resistance in cancer therapy. Nanomedicine. 2010;6(2):210-213.

51. Liu Z, Chen K, Davis C, et al. Drug delivery with carbon nanotubes for in vivo cancer treatment. Cancer Res. 2008;68(16):6652-6660.

52. Wong HL, Rauth AM, Bendayan R, et al. A new polymer-lipid hybrid nanoparticle system increases cytotoxicity of doxorubicin against multidrug-resistant human breast cancer cells. Pharm Res. 2006;23(7): $1574-1585$.

53. nih.gov. US National Institute of Health, A Story of Discovery: HER2's Genetic Link to Breast Cancer Spurs Development of New Treatments. Available from: https://www.cancer.gov/research/progress/discovery/ HER2. Accessed May 20, 2017.

54. Gianni L, Pienkowski T, Im YH, et al. 5-year analysis of neoadjuvant pertuzumab and trastuzumab in patients with locally advanced, inflammatory, or early-stage HER2-positive breast cancer (NeoSphere): a multicentre, open-label, phase 2 randomised trial. Lancet Oncol. 2016;17(6):791-800.

55. Ding H, Gangalum PR, Galstyan A, et al. HER2-positive breast cancer targeting and treatment by a peptide-conjugated mini nanodrug. Nanomedicine. 2017;13(2):631-639.

56. Karmakar A, Bratton SM, Dervishi E, et al. Ethylenediamine functionalized-single-walled nanotube (f-SWNT)-assisted in vitro delivery of the oncogene suppressor $\mathrm{p} 53$ gene to breast cancer MCF-7 cells. Int $J$ Nanomedicine. 2011;6:1045-1055.

57. Day ES, Bickford LR, Slater JH, Riggall NS, Drezek RA, West JL. Antibody-conjugated gold-gold sulfide nanoparticles as multifunctional agents for imaging and therapy of breast cancer. Int J Nanomed. 2010;5:445-454

58. Tang Y, Soroush F, Tong Z, Kiani MF, Wang B. Targeted multidrug delivery system to overcome chemoresistance in breast cancer. Int $J$ Nanomed. 2017;12:671-681.

59. Cai Z, Chattopadhyay N, Yang K, et al. 111 In-labeled trastuzumabmodified gold nanoparticles are cytotoxic in vitro to HER2-positive breast cancer cells and arrest tumor growth in vivo in athymic mice after intratumoral injection. Nucl Med Biol. 2016;43(12):818-826.

60. Jitariu AA, Cîmpean AM, Ribatti D, Raica M. Triple negative breast cancer: the kiss of death. Oncotarget. Epub 2017 Apr 7.

61. Gadi VK, Davidson NE. Practical approach to triple-negative breast cancer. J Oncol Pract. 2017;13(5):293-300.

62. Masuda H, Zhang D, Bartholomeusz C, Doihara H, Hortobagyi GN, Ueno NT. Role of epidermal growth factor receptor in breast cancer. Breast Cancer Res Treat. 2012;136(2):331-345.

63. Chen G, Wang Y, Xie R, Gong S. Tumor-targeted pH/redox dualsensitive unimolecular nanoparticles for efficient siRNA delivery. J Control Release. Epub 2017 Feb 1.

64. Shu D, Li H, Shu Y, et al. Systemic delivery of anti-miRNA for suppression of triple negative breast cancer utilizing RNA nanotechnology. ACS Nano. 2015;9(10):9731-9740.

65. Mamot C, Ritschard R, Wicki A, et al. Immunoliposomal delivery of doxorubicin can overcome multidrug resistance mechanisms in EGFR-overexpressing tumor cells. J Drug Target. 2012;20(5): 422-432.

66. Sheikh UN, Cohen C, Siddiqui MT. Folate receptor alpha immunohistochemistry in cytology specimens of metastatic breast carcinoma. Acta Cytol. 2015;59(4):298-304.

67. Paulmurugan R, Bhethanabotla R, Mishra K, et al. Folate receptortargeted polymeric micellar nanocarriers for delivery of orlistat as a repurposed drug against triple-negative breast cancer. Mol Cancer Ther. 2016;15(2):221-231.
68. Sneider A, Jadia R, Piel B, VanDyke D, Tsiros C, Rai P. Engineering remotely triggered liposomes to target triple negative breast cancer. Oncomedicine. 2017;2:1-13.

69. Parker N, Turk MJ, Westrick E, Lewis JD, Low PS, Leamon CP. Folate receptor expression in carcinomas and normal tissues determined by a quantitative radioligand binding assay. Anal Biochem. 2005;338(2): 284-293.

70. Xu C, Zhao H, Chen H, Yao Q. CXCR4 in breast cancer: oncogenic role and therapeutic targeting. Drug Des Devel Ther. 2015;9:4953-4964.

71. Guo P, You JO, Yang J, Jia D, Moses MA, Auguste DT. Inhibiting metastatic breast cancer cell migration via the synergy of targeted, $\mathrm{pH}$ triggered siRNA delivery and chemokine axis blockade. Mol Pharm. 2014;11(3):755-765.

72. Li H, Wang K, Yang X, et al. Dual-function nanostructured lipid carriers to deliver IR780 for breast cancer treatment: anti-metastatic and photothermal anti-tumor therapy. Acta Biomater. 2017;53:399-413.

73. Schwarz-Cruz YCA, Espinosa M, Maldonado V, Melendez-Zajgla J. Advances in the knowledge of breast cancer stem cells. A review. Histol Histopathol. 2016;31(6):601-612.

74. Mattheolabakis G, Milane L, Singh A, Amiji MM. Hyaluronic acid targeting of CD44 for cancer therapy: from receptor biology to nanomedicine. J Drug Target. 2015;23(7-8):605-618.

75. Gener P, Gouveia LP, Sabat GR, et al. Fluorescent CSC models evidence that targeted nanomedicines improve treatment sensitivity of breast and colon cancer stem cells. Nanomedicine. 2015;11(8):1883-1892.

76. Muntimadugu E, Kumar R, Saladi S, Rafeeqi TA, Khan W. CD44 targeted chemotherapy for co-eradication of breast cancer stem cells and cancer cells using polymeric nanoparticles of salinomycin and paclitaxel. Colloids Surf B Biointerfaces. 2016;143:532-546.

77. Rao W, Wang H, Han J, et al. Chitosan-decorated doxorubicinencapsulated nanoparticle targets and eliminates tumor reinitiating cancer stem-like cells. ACS Nano. 2015;9(6):5725-5740.

78. Wang H, Agarwal P, Zhao S, et al. Hyaluronic acid-decorated dual responsive nanoparticles of Pluronic F127, PLGA, and chitosan for targeted co-delivery of doxorubicin and irinotecan to eliminate cancer stem-like cells. Biomaterials. 2015;72:74-89.

79. Zhao P, Lu Y, Jiang X, Li X. Clinicopathological significance and prognostic value of CD133 expression in triple-negative breast carcinoma. Cancer Sci. 2011;102(5):1107-1111.

80. Swaminathan SK, Roger E, Toti U, Niu L, Ohlfest JR, Panyam J. CD133targeted paclitaxel delivery inhibits local tumor recurrence in a mouse model of breast cancer. J Control Release. 2013;171(3):280-287.

81. Carcereri de Prati A, Butturini E, Rigo A, et al. Metastatic breast cancer cells enter into dormant state and express cancer stem cells phenotype under chronic hypoxia. J Cell Biochem. Epub 2017 Mar 6.

82. Qiao S, Zhao Y, Geng S, et al. A novel double-targeted nondrug delivery system for targeting cancer stem cells. Int J Nanomed. 2016;11: 6667-6678.

83. Van Sluis R, Bhujwalla ZM, Raghunand N, et al. In vivo imaging of extracellular pH using 1 H MRSI. Magn Reson Med. 1999;41(4):743-750.

84. Muntimadugu E, Kommineni N, Khan W. Exploring the potential of nanotherapeutics in targeting tumor microenvironment for cancer therapy. Pharmacol Res. Epub 2017 May 13.

85. Pramanik P, Halder D, Jana SS, Ghosh S. pH-Triggered Sustained Drug Delivery from a Polymer Micelle having the $\beta$-Thiopropionate Linkage. Macromol Rapid Commun. 2016;37(18):1499-1506.

86. Cheng B, Lu B, Liu X, et al. A pH-responsive glycolipid-like nanocarrier for optimising the time-dependent distribution of free chemical drugs in focal cells. Int J Pharm. 2017;522(1):210-221.

87. Jiang L, He B, Pan D, Luo K, Yi Q, Gu Z. Anti-cancer efficacy of paclitaxel loaded in pH triggered liposomes. J Biomed Nanotechnol. 2016; 12(1):79-90.

88. Ng KE, Amin MCIM, Katas H, et al. pH-Responsive Triblock Copolymeric Micelles Decorated with a Cell-Penetrating Peptide Provide Efficient Doxorubicin Delivery. Nanoscale Res Lett. 2016;11(1):539.

89. Xu CF, Zhang HB, Sun CY, et al. Tumor acidity-sensitive linkagebridged block copolymer for therapeutic siRNA delivery. Biomaterials. 2016;88:48-59. 
90. Velaei K, Samadi N, Barazvan B, Soleimani Rad J. Tumor microenvironment-mediated chemoresistance in breast cancer. Breast. 2016;30:92-100.

91. Liu P, Wang Z, Brown S, et al. Liposome encapsulated Disulfiram inhibits NFKB pathway and targets breast cancer stem cells in vitro and in vivo. Oncotarget. 2014;5(17):7471-7485.

92. Pham E, Yin M, Peters CG, et al. Preclinical efficacy of bevacizumab with CRLX101, an investigational nanoparticle-drug conjugate, in treatment of metastatic triple-negative breast cancer. Cancer Res. 2016;76(15):4493-4503.

93. Conley SJ, Baker TL, Burnett JP, et al. CRLX101, an investigational camptothecin-containing nanoparticle-drug conjugate, targets cancer stem cells and impedes resistance to antiangiogenic therapy in mouse models of breast cancer. Breast Cancer Res Treat. 2015; 150(3):559-567.

94. Noy R, Pollard JW. Tumor-associated macrophages: from mechanisms to therapy. Immunity. 2014;41(1):49-61.

95. Cullis JE, Siolas D, Avanzi A, Barui S, Maitra A, Bar-Sagi D. Macropinocytosis of nab-paclitaxel drives macrophage activation in pancreatic cancer. Cancer Immunol Res. 2017;5(3):182-190.

96. Zhang X, Tian W, Cai X, et al. Hydrazinocurcumin encapsuled nanoparticles "re-educate" tumor-associated macrophages and exhibit anti-tumor effects on breast cancer following STAT3 suppression. PLoS One. 2013;8(6):e65896.

97. Niu M, Valdes S, Naguib YW, Hursting SD, Cui Z. Tumor-associated macrophage-mediated targeted therapy of triple-negative breast cancer. Mol Pharm. 2016;13(6):1833-1842.

98. Wiseman BS, Werb Z. Stromal effects on mammary gland development and breast cancer. Science. 2002;296(5570):1046-1049.

99. Mikhaylov G, Klimpel D, Schaschke N, et al. Selective targeting of tumor and stromal cells by a nanocarrier system displaying lipidated cathepsin b inhibitor. Angew Chem Int Ed Engl. 2014;53(38): 10077-10081.

100. Ernsting MJ, Murakami M, Undzys E, Aman A, Press B, Li S-D. A docetaxel-carboxymethylcellulose nanoparticle outperforms the approved taxane nanoformulation, Abraxane, in mouse tumor models with significant control of metastases. J Control Release. 2012;162(3): 575-581.

101. Murakami M, Ernsting MJ, Undzys E, Holwell N, Foltz WD, Li SD. Docetaxel conjugate nanoparticles that target $\alpha$-smooth muscle actinexpressing stromal cells suppress breast cancer metastasis. Cancer Res. 2013;73(15):4862-4871.
102. Hoang B, Ernsting MJ, Roy A, Murakami M, Undzys E, Li SD. Docetaxel-carboxymethylcellulose nanoparticles target cells via a SPARC and albumin dependent mechanism. Biomaterials. 2015;59: 66-76.

103. Banerjee J, Hanson AJ, Gadam B, et al. Release of liposomal contents by cell-secreted matrix metalloproteinase-9. Bioconjug Chem. 2009;20(7):1332-1339.

104. Qin C, He B, Dai W, et al. Inhibition of metastatic tumor growth and metastasis via targeting metastatic breast cancer by chlorotoxinmodified liposomes. Mol Pharm. 2014;11(10):3233-3241.

105. Yang D, Feng L, Dougherty CA, et al. In vivo targeting of metastatic breast cancer via tumor vasculature-specific nano-graphene oxide. Biomaterials. 2016;104:361-371.

106. Marquette C, Nabell L. Chemotherapy-resistant metastatic breast cancer. Curr Treat Options Oncol. 2012;13(2):263-275.

107. Wind NS, Holen I. Multidrug resistance in breast cancer: from in vitro models to clinical studies. Int J Breast Cancer. 2011;2011:967419.

108. Wong HL, Bendayan R, Rauth AM, Wu XY. Simultaneous delivery of doxorubicin and GG918 (Elacridar) by new polymer-lipid hybrid nanoparticles (PLN) for enhanced treatment of multidrug-resistant breast cancer. J Control Release. 2006;116(3):275-284.

109. Katiyar SS, Muntimadugu E, Rafeeqi TA, Domb AJ, Khan W. Codelivery of rapamycin-and piperine-loaded polymeric nanoparticles for breast cancer treatment. Drug Deliv. 2016;23(7):2608-2616.

110. Baek JS, Cho CW. A multifunctional lipid nanoparticle for co-delivery of paclitaxel and curcumin for targeted delivery and enhanced cytotoxicity in multidrug resistant breast cancer cells. Oncotarget. 2017;8(18):30369-30382.

111. Hu C, Gu F, Tai Z, et al. Synergistic effect of reduced polypeptide micelle for co-delivery of doxorubicin and TRAIL against drugresistance in breast cancer. Oncotarget. 2016;7(38):61832-61844.

112. Zhao Y, Huan ML, Liu M, et al. Doxorubicin and resveratrol codelivery nanoparticle to overcome doxorubicin resistance. Sci Rep. 2016;6:35267.

113. Gao M, Xu Y, Qiu L. Sensitization of multidrug-resistant malignant cells by liposomes co-encapsulating doxorubicin and chloroquine through autophagic inhibition. J Liposome Res. 2017;27(2):151-160.
International Journal of Nanomedicine

\section{Publish your work in this journal}

The International Journal of Nanomedicine is an international, peerreviewed journal focusing on the application of nanotechnology in diagnostics, therapeutics, and drug delivery systems throughout the biomedical field. This journal is indexed on PubMed Central, MedLine, CAS, SciSearch $®$, Current Contents ${ }^{\circledR} /$ Clinical Medicine,

\section{Dovepress}

Journal Citation Reports/Science Edition, EMBase, Scopus and the Elsevier Bibliographic databases. The manuscript management system is completely online and includes a very quick and fair peer-review system, which is all easy to use. Visit http://www.dovepress.com/ testimonials.php to read real quotes from published authors. 